Journal of

Literary Education

\title{
Student Teachers and Kindergarten Children Talking about Picturebooks Focusing School in Didactic Research Labs at University
}

\author{
Estudiantes de Magisterio y alumnado de Infantil hablan sobre \\ álbumes centrados en la escuela en laboratorios didácticos de \\ investigación en la Universidad
}

\author{
Estudiants de Magisteri i alumnat d'Infantil parlen sobre àlbums \\ centrats a l'escola en laboratoris didàctics de recerca a la universitat
}

\author{
Jeanette Hoffmann. Free University of Bozen-Bolzano, Italy. \\ jeanette.hoffmann@unibz.it \\ https://orcid.org/0000-0003-1959-3718
}

\begin{abstract}
As part of the project "Lehren, Lernen und Forschen in Werkstätten" (Teaching, Learning and Researching in Laboratories) from 2016 to 2019, seminars on German language and literature didactics were held at the "Lern- und Forschungswerkstatt Grundschule" (LuFo, Primary Education Research Lab) at the Technische Universität (TU) Dresden. The seminars, which were attended by student primary school teachers, dealt with telling stories using wordless picturebooks, reading aloud picturebooks about school or other topics. The student teachers dealt with selected picturebooks from the perspective of literature didactics, visual literacy studies and empirical research on reading engagement. They designed didactic arrangements (different kinds of didactically based activities by students with children in a literary-aesthetic context) following the principles of inquiry-based learning and invited kindergarten and primary school children to the LuFo to explore the stories told in the picturebooks together. The study is based on the student teachers' seminar papers in which they describe their projects, give didactic reasons for the selection of literature and analyse their interactions with the children around the picturebooks. Using the example of picturebooks about school, the study uses Key Incident Analysis to ask which books the student teachers chose and how they read them, how they talked to and interacted with the children about them and how they shaped the reading situations. Finally, they asked how they reflected on their own learning processes. The results give an insight into both the processes of reflection of the primary school student teachers and the processes of literary learning of the children.

Key words: Reading engagement, Visual literacy, Picturebooks, Primary education, Inquiry-based learning
\end{abstract}




\section{Resumen}

Como parte del proyecto "Lehren, Lernen und Forschen in Werkstätten" (Enseñar, Aprender e Investigar en Laboratorios) es llevaron a cabo seminarios sobre didáctica de la lengua y la literatura alemana en la "Lern- und Forschungswerkstatt Grundschule" (LuFo, Laboratorio de Investigación de Educación Primaria) en la Technische Universität (TU) de Dresden del 2016 al 2019. Los seminarios, a los cuales asistieron estudiantes de Magisterio de Primaria, versó sobre contar historias a través de álbumes ilustrados sin palabras, y se leyó en voz alta álbumes ilustrados sobre la escuela y otros temas. El alumnado de Magisterio se enfrentó a álbumes ilustrados seleccionados desde la perspectiva de la didáctica de la literatura, desde los estudios sobre alfabetización visual y desde la investigación empírica en animación lectora. Diseñaron dispositivos didácticos (diferentes tipos de actividades didácticas realizadas por el estudiantado con niños y niñas en un contexto literario-estético) siguiendo los principios del aprendizaje basado en la indagación e invitaron a alumnado de Educación Infantil y Primaria al LuFo para explorar juntos las historias que se narraban en los álbumes ilustrados. Este estudio está basado en los documentos del seminario de los y las estudiantes de Magisterio en los cuales describen sus proyectos, dan razones de tipo didáctico para la selección de la literatura y analizan sus interacciones con el alumnado acerca de los álbumes. Utilizando el ejemplo de los álbumes sobre la escuela, el estudio utiliza el Análisis de Incidentes Críticos (Key Incidents Analysis) para preguntar qué libros escogían los y las alumnos y alumnas de Magisterio, cómo los leían, cómo hablaban sobre ellos y con quién, y cómo interactuaban acerca de estos con niños y niñas y también como daban forma a las situaciones de lectura. Finalmente, también se preguntaron sobre cómo lo reflejaban en sus procesos de aprendizaje. Los resultados se acercan a los dos procesos de reflexión. Por una parte el del alumnado de Magisterio Educación Primaria y por otro el de los procesos de aprendizaje de los niños y niñas.

Palabras clave: Animación lectora, alfabetización visual, álbumes ilustrados, Educación Primaria, aprendizaje basado en la indagación

\section{Resum}

Com a part del projecte "Lehren, Lernen und Forschen in Werkstätten" (Ensenyar, Aprendre i Investigar en Laboratoris), es van dur a terme seminaris sobre didàctica de la llengua i literatura alemanyes a la "Lern- und Forschungswerkstatt Grundschule" (LuFo, Laboratori de Recerca d'Educació Primària) a la Technische Universität (TU) de Dresden del 2016 al 2019. Els seminaris, als quals van assistir estudiants de Magisteri de Primària, va versar sobre contar històries a través d'àlbums il-lustrats sense paraules, i es va llegir en veu alta àlbums il-lustrats sobre l'escola i d'altres temes. L'alumnat de Magisteri va enfrontar-se amb àlbums il-lustrats seleccionats des de la perspectiva de la didàctica de la literatura, des dels estudis sobre alfabetització visual i des de la recerca empírica en animació lectora. Van dissenyar dispositius didàctics (diferents tipus d'activitats didàctiques realitzades per estudiantat amb infants en un context literari-estètic) tot seguint els principis de l'aprenentatge basat en la indagació i van convidar infants d'Educació Infantil i Primària al LuFo per tal d'explorar tots junts les històries que es narraven als àlbums il-lustrats. Aquest estudi està basat en els documents del seminari dels i les estudiants de Magisteri en els quals descriuen els seus projectes, donen raons de caire didàctic per a la selecció de la literatura i analitzen les seues interaccions amb els infants al voltant dels àlbums. Tot utilitzant l'exemple dels àlbums sobre l'escola, l'estudi utilitza l'Anàlisi d'Incidents Crítics (Key Incidents Analysis) per tal de preguntar quins llibres triaven els i les alumnes de Magisteri, com els llegien, com en parlaven i amb qui, i com n'interactuaven al seu voltant amb infants i també com donaven forma a les situacions de lectura. Finalment, també es van preguntar sobre com els reflectien en els seus processos d'aprenentatge. Els resultats s'acosten a tots dos processos de reflexió: els de l'alumnat de Magisteri Educació Primària i els dels processos d'aprenentatge literari dels infants. 
Paraules clau: Animació lectora, alfabetització visual, àlbums il·lustrats, Educació Primària, aprenentatge basat en la indagació

\section{Introduction}

Children's literature as a university subject of learning is relevant to both children's literature research, but also to the training of future educators and teachers, especially future primary school teachers. The aim of such studies is to learn about a diverse range of contemporary children's literature, to explore its "experientiality" (Fludernik, 2009), to recognise its literary-aesthetic potential and to be able to build up a "repertoire of stories" (Dehn et al., 2014) during ones studies. A further step is the ability to independently select children's literature and to design didactic arrangements. This term is used in this paper to refer to different kinds of didactically based activities by students with children in a literary-aesthetic context. In order for this selection and designing process to not remain at a theoretical level but to become an experiential learning process for the student teachers, authentic situations of trying things out, of joint encounters between student teachers and children in conversation about literature are necessary. One setting for such literary encounters at universities can be Laboratories that are equipped with a rich material landscape for storytelling (e.g. kamishibai, stick figures, story boxes, theatre cases) and with a variety of children's literature and that can also be spatially designed as reading places with the help of flexible furniture arrangements (sofas, seat cubes, seat cushions). Beyond these spatial resources, however, there is also a need for teaching formats that make use of this potential and use it for inquiry-based learning (Huber, 2013; Mieg, 2019). This article deals with such a format in the form of Didactic Research Laboratories (Hoffmann et al., 2019). After a discussion of the theoretical background and the project context, the concept of Didactic Research Laboratories is presented and explained using an example. Key incident analyses (Kroon \& Sturm, 2007) of a reading aloud workshop conducted by student teachers with kindergarten children are then reported, revealing

diverse learning potentials of children and student teachers alike. The article concludes by considering the point of view of higher education didactics. 


\section{Context}

\subsection{Theoretical context}

Children's literature occupies a significant place in children's lives. Children grow up in a sea of stories (Bruner, 1996) and acquire the world narratively, because learning and narration are closely linked. In doing so, they increasingly move in different worlds, that of reality and that of fiction. Both worlds complement each other and refer to each other (Wieler, 2018). The acquisition of the ability to imagine as the basis of literary learning (Spinner, 2006) plays a central role in linking these different worlds, relating reality and fiction to each other, and thereby expanding one's own scope of action. In imagination, children learn to think in drafts (Ulich \& Ulich, 1994) and to imagine "possible worlds" (Bruner, 1986). For the initiation of these cognitive learning processes in language and literature acquisition, the social context plays a decisive role. Children's reception of literature is embedded in a social context and is structured dialogically and narratively (Wieler et al., 2008). From an early age, rhymes are recited together with competent others, finger games are played, songs are sung, stories are told, and picturebooks are read aloud. In this context, multimodal approaches to stories are significant (Naujok, 2018). Language and literature acquisition are closely linked to this. In order to sensitise future educators and teachers to the importance of children's literature in their studies of childhood education or primary education, there is a need for experiential spaces that allow them to learn more about children's literature and in its dialogical appropriation in interactions with children (Hoffmann, 2020). This article aims to provide an example of the 'opening' of these literary spaces of possible worlds in university studies.

\subsection{Project context}

This section outlines the context of the research project from which the analyses originate. The project "Lehren, Lernen und Forschen in Werkstätten" (Teaching, Learning and Researching in Laboratories) was a sub-project of the package of measures called "Synergetische Lehrerbildung im exzellenten Rahmen" (Synergetic teacher education in a framework of excellence, TUD-Sylber) and was funded by the "Bundesministerium für Bildung und Forschung" (BMBF) as part of the "Qualitätsoffensive Lehrerbildung" from 2016-2019. Its aim was to develop and evaluate learning formats following the principles of inquiry-based learning at university laboratories. In cooperation with other sub-projects of this research context, questions about fields of tension between theory and practice in teacher education - as the German title "Spannungsfelder zwischen Theorie und Praxis in der Lehrer/innenbildung" (Areas of tension between theory and practice in teacher 
education, Ertl-Schmuck \& Hoffmann, 2020) of the collective volume from the project group suggests - were dealt with from an interdisciplinary perspective.

The "Lern- und Forschungswerkstatt Grundschule" (LuFo) (Primary Education Research Lab) at the TU Dresden was created in 2013 and was developed and lead by this author in cooperation with other colleagues (Hoffmann et al., 2019, Figure. 1). The LuFo is conceived as a stimulating learning environment with diverse language and literature didactic materials and an extensive collection of contemporary children's literature, with a focus on picturebooks. These offer student teachers an insight into children's life worlds and open numerous storytelling, talking and writing opportunities with children. In this way, future teachers can build up a "story repertoire" (Dehn et al., 2014) during their studies, which they can draw on in their later teaching practice.
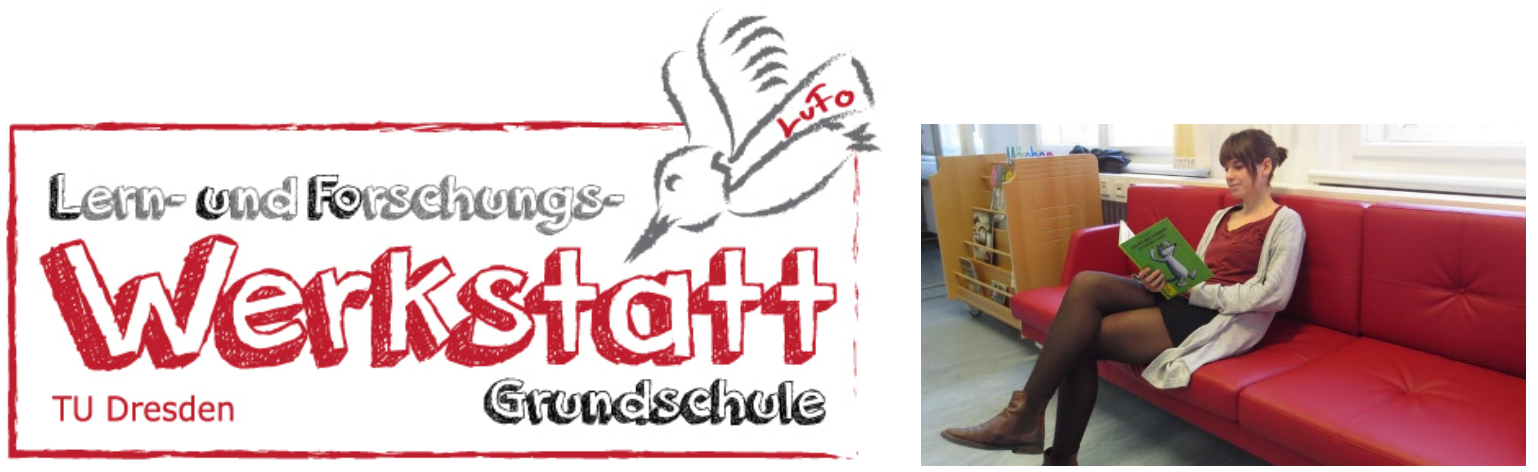

Figure. 1. Logo and interior view of the LuFo (Lern- und Forschungswerkstatt Grundschule)

Once a semester, groups of children from kindergarten, primary school and secondary school are regularly invited to the LuFo in seminars designed as "Didactic Research Labs" (Hoffmann et al., 2019; Herrmann, 2019). Student teachers at the LuFo prepare didactic arrangements with a focus on various topics for these seminars. They carry these out with the children and reflect on their observations and experiences in terms of inquirybased learning (Huber, 2013; Mieg, 2019). In the The LuFo is conceived as a stimulating learning environment with diverse language and literature didactic materials and an extensive collection of contemporary children's literature, with a focus on picturebooks. These offer student teachers an insight into children's life worlds and open numerous storytelling, talking and writing opportunities with children. Didactic Research Lab, the children were invited to tell stories, read, draw, write and talk to each other about children's literature. In all these 
activities, the focus was on literary-aesthetic approaches. Didactic Research Labs were designed and implemented on the following topics during the project period:

- 2016, 2018, 2019 Creative Writing,

- 2017 Reading Interests of Boys and Girls,

- 2017 Storytelling on Textless Picturebooks,

- 2018 "Language" Exhibition at the Museum,

- 2018 Graphic Literature and its Reception,

- 2019 Reading Aloud - School in Picturebooks.

The various topics arose in light of research carried out by this author in connection with my former professorship in Primary Education/German Education at TU Dresden, and also in collaboration with cooperation partners or in connection with current events. For example, the Didactic Research Lab on the "'Language' Exhibition at the Museum" (2018) was held in connection with the exhibition shown at the Deutsches Hygiene Museum Dresden (DHMD) "Sprache. Welt der Worte, Zeichen, Gesten" (Language. World of Words, Signs, Gestures) (Schmitz \& Weiss, 2016). The Didactic Research Lab "Reading Aloud - School in Picturebooks" took place in parallel to the lecture series "100 Jahre Grundschule in Deutschland - eine Schule für alle?" (100 Years of Primary School in Germany - A School for All?) (Brandt et al., 2021) on the occasion of the 100th anniversary of the common primary school at the Faculty of Education of the TU Dresden. This particular Didactic Research Lab is the focus of this article.

\section{Didactic Research Lab “Reading Aloud - School in Picturebooks"}

\subsection{Procedure of the Didactic Research Lab}

The Didactic Research Lab consisted of three parts: a preparatory literature study, the conception of the didactic arrangements and their implementation and reflection.

The first part of the Didactic Research Lab "Reading Aloud - School in Picturebooks" was organised in the form of reading of academic texts at home and joint seminar discussions in the whole group. The student teachers first engaged with storytelling between picture and text from a literary studies perspective and learned about analysis models for picturebooks (Staiger, 2013; KümmerlingMeibauer, 2014). Afterwards they engaged with the topic empirically from the perspective of 
literary socialisation research (Arizpe et al., 2014; Wieler, 2014), considering how children acquire language and literature in interaction with other children and adults. Then the student teachers discussed the didactic approach of dialogical reading aloud (Spinner, 2005; Merklinger \& Preußer, 2014). Finally, they learned about pedagogical observation (de Boer, 2012) and key incident analysis (Kroon \& Sturm, 2007) from a research methodological perspective.

In the second part of the Didactic Research Lab, the student teachers worked freely in groups. Here, the focus was on dialogical learning in the teacher students' groups (Wells, 2015). They made various joint selection decisions concerning which picturebook to use, which didactic approaches to take and which materials to use. Very practical organisational considerations also needed to be made (who would greet the groups of children on arrival, where the children could hang up their jackets, and where they could eat their sandwiches after the sometimes long journey to the university).

Finally, in the third part, the student teachers implemented their didactic arrangements with the groups of children. Half of the group always conducted the reading aloud workshop and the other half observed the interactions from an ethnographic perspective; this is discussed in more detail below. Following the implementations, joint reflection rounds took place in the entire seminar before the student teachers continued to develop their reflections in writing the seminar papers.

The following section explains these individual phases in more detail, based on the concrete implementation of the Didactic Research Lab, before analyses of a selected reading aloud workshop are carried out.

\subsection{Selection of picturebooks for the Didactic Research Lab}

In the run-up to the Didactic Research Lab "Reading Aloud - School in Picturebooks", a selection of picturebooks was made; all the books were about school, in particular about starting primary school, meaning that an important transition in the development from kindergarten child to school child is thematised. From a socio-ecological perspective, it has been shown that media, including picturebooks, can support children in coping with transitions within and between different socioecological zones (Vollbrecht, 2010; Wegener, 2018): between the centre (the family), the local space (the neighbourhood or living environment), the outskirts (such as kindergarten, school or sports club) and the periphery (excursions, holidays or visits) (Baacke, 2018a; Baacke 2018b). Starting primary school represents a transition within the socio-ecological zone of outskirts and is 
thematically and narratively taken up in extremely diverse ways in children's literature, especially in picturebooks, comics and first reading books (Hoffmann, 2021). In the study "Erzählen in Texten und Bildern - Graphic Novels im Deutschunterricht" (Narrating in Texts and Pictures - Graphic Novels in German Lessons), Hoffmann $(2017$; 2021) showed, with qualitative-empirical analyses, that school entry is significant for children even at the end of their primary school years and that graphic narrative stories about school entry offer numerous narrative and writing occasions for joint remembering. A total of 21 picturebooks and first reading books were selected in particular for the Didactic Research Lab "Reading Aloud - School in Picturebooks" under discussion. The titles were as follows (ordered by publication date; the bibliography at the end of the article also lists the Englishlanguage versions, if available):

- Ich will auch in die Schule gehen (Lindgren, 1980),

- Nur Mut, Willi Wiberg (Bergström, 1982),

- Ich will in die Schule (Fährmann, 1994),

- Schulgeschichten vom Franz (Nöstlinger, 1987),

- Als ich klein war (Gaetzi, 1999),

- Philipok (Tolstoj \& Beneduce, 2000),

- Kwatsch. Julius P. (Scieszka, 2001),

- Nein! Zur Schule geh ich nicht! (Child, 2005),

- Zwei dicke Freundinnen (Schärer, 2006),

- Flunkerfisch (Donaldson, 2007),

- Garmans Sommer (Hole, 2009),

- Meine Mutter ist in Amerika und hat Buffalo Bill getroffen (Regnaud, 2009),

- Regenwurmtage (Damm, 2011),

- Nur Mut, kleiner Luis (Ramos, 2012),

- Die coolste Schule der Welt (Hula, 2013),

- Wir sind 1a (Teich, 2014),

- Frau Hoppes erster Schultag (Bertron, 2016),

- Liebe Grüße, deine Giraffe (Iwasa, 2017),

- Der Bär ist los! Warum Bären nicht in die Schule gehören (Sperring, 2018),

- Die Schule (Teckentrup, 2018),

- Wenn ich in die Schule geh, siehst du was, was ich nicht seh (Völk, 2018). 
In addition to a few widely popular titles from the 1980s and 1990s (e.g. Lindgren, 1980; Bergström, 1982), the list included in particular recent, and also "challenging and controversial" (Evans, 2015), titles from the 2000s and 2010s, some of which were nominated for the "Deutscher Jugendliteraturpreis" (German Youth Literature Award) as picturebooks (Scieszka, 2001; Hole, 2009) or as children's books (Regnaud, 2009; Iwasa, 2017). Overall, a wide variety of stories focused on being afraid and being brave, dreaming and being curious, being late and lying, or being excluded and being different. Some picturebooks are aimed more at a preschool age (e.g. Donaldson, 2007; Sperring, 2018), others at an advanced primary school age (e.g. Regnaud, 2009; Teckentrup, 2018). What all these stories have in common is that they take the child's perspective and take their worries and needs, and also their thirst for exploration and knowledge, seriously.

During the selection process, the books were spread out on a long table and the student teachers were invited to browse them. The students were asked to form groups through the books and to enter into conversation with each other. The books were then exhibited in connection with the 100th anniversary of the primary school during the "Lange Nacht der Werkstätten" (Long Night of Laboratories) as part of the TU Dresden's “Lange Nacht der Wissenschaften” (Long Night of Science) during which the TU Dresden opens its doors to all those interested and provides an insight into current research and teaching projects.

\subsection{Student teachers' choice of picturebooks}

The student teachers formed four groups of five to eight student teachers and were asked to select one picturebook per group. The four books chosen were (Figure 2): Nur Mut, Willi Wiberg (Bergström, 1982), Philipok (Tolstoj \& Beneduce, 2000), Flunkerfisch (Donaldson, 2007) and Wenn ich in die Schule geh, siehst du was, was ich nicht seh (Völk, 2018).
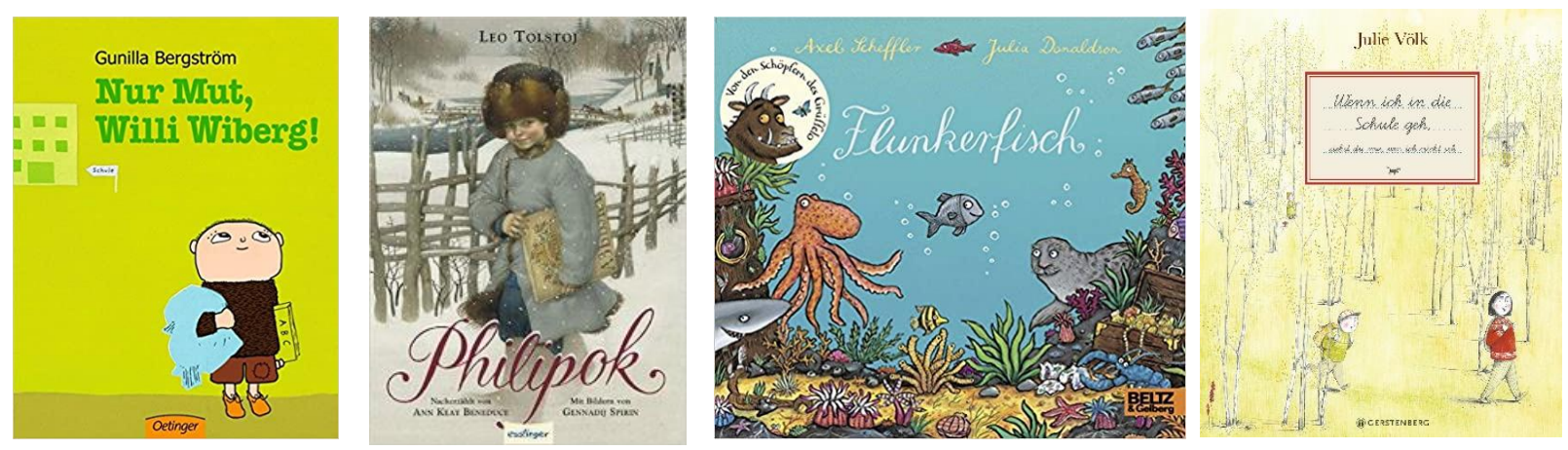

Figure. 2. Covers of the picturebooks selected by the student teachers (Bergström, 1982; Tolstoj \& Beneduce, 2000; Donaldson, 2007; Völk, 2018) 
Overall, the student teachers drew on international children's literature from different linguisticcultural contexts (Swedish, Russian, English, German/Austrian). Different styles of drawing and narration can also be discerned. It is noticeable that against the background of the literature offered, the student teachers increasingly fell back on the familiar, such as the literary classic by Tolstoy, the Willi Wiberg stories, which some presumably know from their own childhood, or the author and illustrator duo Scheffler and Donaldson, well known from their book The Gruffalo. Only one group of student teachers moved into unfamiliar territory and chose a wordless picturebook, which was published the year before the seminar: Wenn ich in die Schule geh, siehst du was, was ich nicht seh (When I go to school you see something I don't see) by Juli Völk (2018), a young author and illustrator from Austria. The picturebook was nominated by Deutschlandfunk 2018 for "Die besten $7 \mathrm{im}$ Oktober" (The Best 7 in October). It tells the story of a brother and sister on their way to school in the early morning, from saying goodbye to their parents to sitting at their desks in the classroom. The focus is on the journey to school, where they meet many other children and there are numerous wonderful and strange things to see. The picturebook tells the story 'quietly', not only by not using words, but also through the use of pictures in soft tones and light shading. The double-page spreads are designed as hidden object pictures, with numerous side stories that literally distract from the route to school again and again. The cover is reminiscent of a school exercise book, with the typography of the title in cursive script on a lined background within a frame that is typical of exercise books. In this way, school or the journey to school is not only taken up in terms of content, but also told visually.

The following section presents the conception of the reading aloud workshop on the picturebook described in the previous paragraph by the group of student teachers, followed by empirical analyses of selected aspects.

\section{Reading aloud workshop Wenn ich in die Schule geh, siehst du was, was ich nicht seh}

\subsection{Preparation and implementation of a didactic arrangement}

In the reading aloud workshop When I go to school... the student teachers prepared a didactic arrangement that enabled different multimodal approaches (Naujok, 2018) to the picturebook. The target group was a group of seven kindergarten children who were about to start school right after the summer holidays. In this respect, it could be assumed that the journey to school was a significant topic for them. The student teachers had put the chairs and tables in the LuFo to one side and 
prepared a seating circle on the floor with cushions, surrounded by colourful seating cubes. The student teachers chose a playful approach to start the conversation with the children and to introduce them to the picturebook (Figure 3).

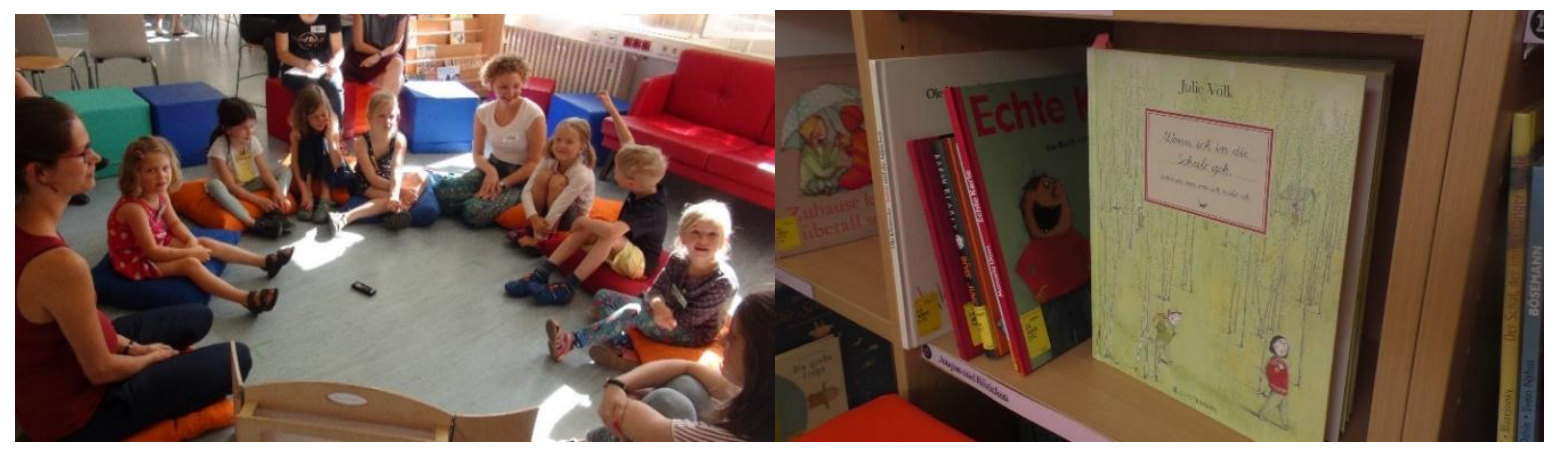

Figure. 3. Playing the game "I see something you don't see" as an introduction to the picturebook

Following the title of the picturebook When I go to school, you see something I don't see, they played the well-known (in Germany) guessing game "Ich sehe was, was du nicht siehst" (I see something you don't see) with the children. The LuFo with its stimulating material landscape, presented on open shelves, provided a rich environment for this. The picturebook itself was in the children's field of vision with the cover facing forward on a shelf, so it was selected as a search object during the game: "I see something you don't see, and it's green." This brought the picturebook into focus and it was now the central object of conversation. Following the concept of the "Bilderbuchkinogespräch" (picturebook cinema discussion) (Hoffmann, 2019) on wordless picturebooks, the student teachers conducted a "picturebook discussion" with the preschool children. They placed the open picturebook in the middle of the sitting circle, looked at the pictures together, let the children talk about them and accompanied and supported this with prepared questions about the story and the characters. The student teachers had set up a kamishibai, a storytelling theatre, with a landscape picture from the picturebook, on which pictures of the characters from the story were gradually hung on to a line. These characters were given invented names to give the children an orientation to the characters of the book.

After the picturebook discussion, the children drew pictures with crayons on paper (Figure 4). The seating cubes were used as impromptu tables. 

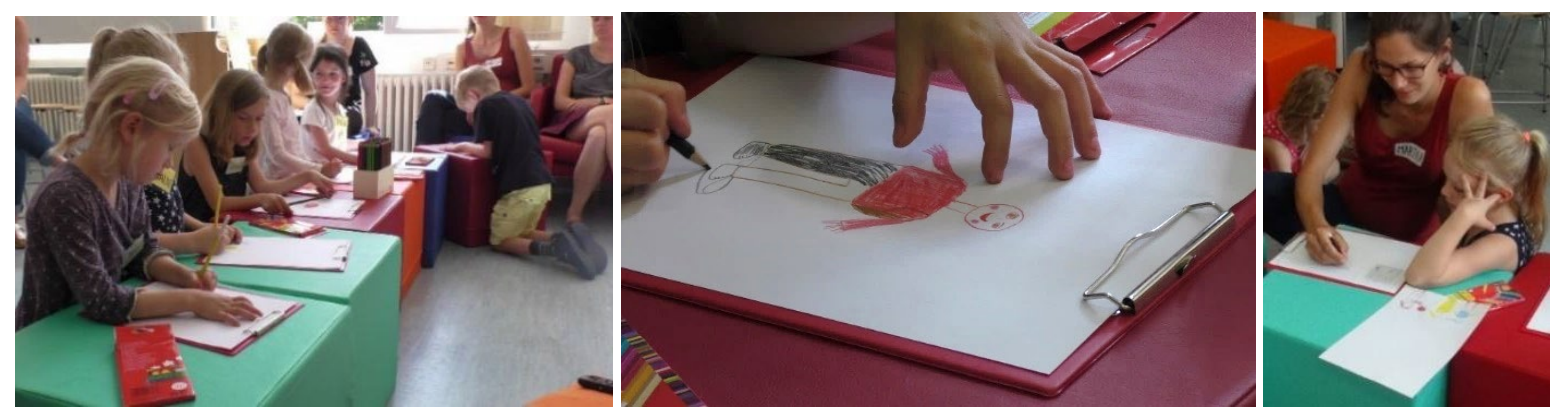

Figure. 4 Drawing and writing to the picturebook

The student teachers then asked the children to write texts to the children's pictures, following the didactic approach "Schreiben zu Vorgaben" (writing to texts/pictures/figures) (Dehn, 2004) by applying the concept of "Diktierendes Schreiben" (dictating writing) (Merklinger, 2011). Finally, the children's texts and pictures were presented to the other children and student teachers in the larger group. This didactic arrangement included multimodal approaches of playing, telling, drawing, and writing to the picturebook.

\subsection{Ethnographic observation and data collection}

Following the principles of inquiry-based learning, the student teachers developed a research question about their project as a starting point. This question related to the children's literary learning processes or their collaborative interactions. While three student teachers of the group carried out the reading aloud workshop with the children, the other two student teachers of the group devoted themselves to ethnographic observation, following the concept of interpretative classroom research (Krummheuer, 2000). They prepared observation protocols of the situations in which they recorded in writing the aspects of interest for their research question. Furthermore, the interactions were recorded with photographs, audio and video. The audio recordings were then transcribed by the student teachers using the "Gesprächsanalytisches Transkriptionssystem" GAT 2 (Conversation Analysis Transcription System, Selting et al., 2009). The video recordings were used to assign the voices to the speakers and to identify and record non-verbal communication if necessary. The children's pictures and texts were scanned in as further data (Figure. 5). 


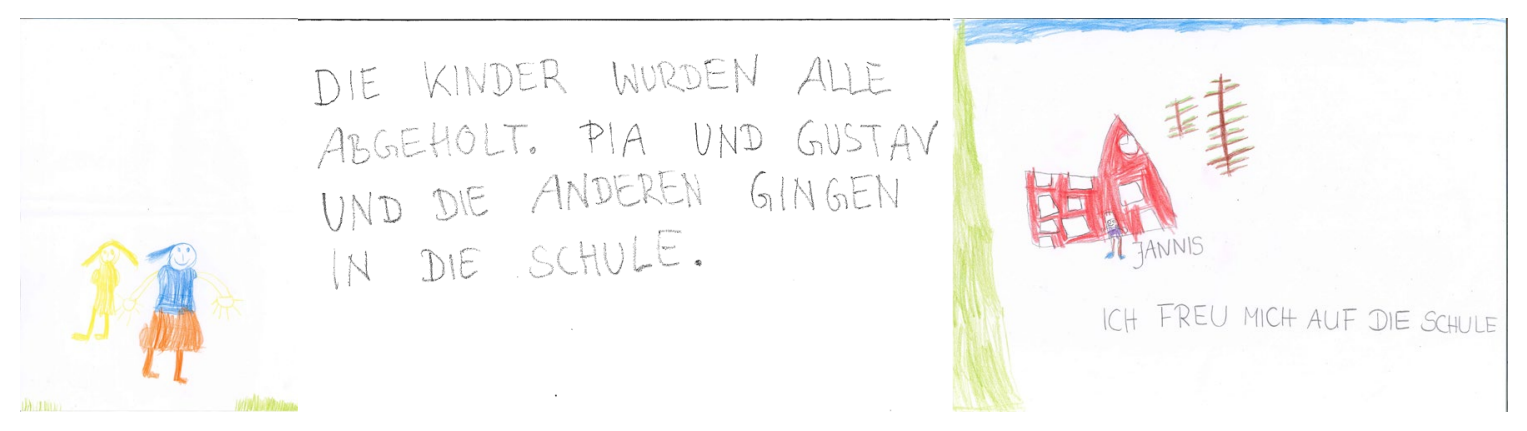

Figure. 5. Children's texts and drawings

This approach, which is both practical and observational, distinguishes the Didactic Research Labs from the teaching placements that student teachers carry out with children in schools. The focus here is on inquiry-based learning (Huber, 2013; Mieg, 2019).

\subsection{Reflections in the seminar and analyses and reflections in seminar papers}

After the reading aloud workshops, the observations were reflected on together in a plenary discussion in the seminar. The lecturer moderated this discussion by asking the student teachers to talk about the course of the reading workshop in general as a first step. Following this, particular "crucial points" and "stumbling points" from the observations were highlighted and presented to the whole seminar for discussion. The focus on the one hand was on the linguistic-literary learning processes of the children, and on the other hand on the pedagogical and literary-didactic learning processes of the student teachers. This common reflection in the seminar served as the basis for the student teachers' subsequent written analyses and reflections in their seminar papers.

\section{Empirical Analyses}

\subsection{Methodological approach}

In the research project "Lehren, Lernen und Forschen in Werkstätten", a total of eight Didactic Research Labs were carried out in three years (see above). Within the Didactic Research Lab "Reading Aloud - School in Picturebooks", four reading aloud workshops using four picturebooks were conducted and documented by the student teachers. A total of 25 children's texts and drawings were produced. The observations and children's products were analysed and reflected upon in writing in eight seminar papers by a total of 17 student teachers. From this corpus of data, an insight into the analyses of the project is given below, using the example of the reading aloud workshop on the picturebook Wenn ich in die Schule geh... (When I go to school...). Following the 
principles of interpretative classroom research (Krummheuer, 2000), different data sources were triangulated. The following analyses are thus based on both the conversation transcript from the picturebook discussion and the student teachers' seminar papers. Individual excerpts are selected from these data and analysed with the help of "Key Incident Analysis" (Kroon \& Sturm, 2007). With this type of analysis, important details provide perspectives on fundamental structures of the whole. The central research questions in this paper are:

- How do student teachers choose their picturebook and how do they deal with the picturebook's ambiguity and openness to interpretation?

- What do they choose for didactic foundation of their research question and their didactic arrangement?

- How do student teachers create links between fiction and reality when talking with children about a wordless picturebook?

- What insights do student teachers gain into the research process and how do they gain them?

\subsection{Picturebook selection by student teachers}

With the selection of the picturebook (Figure. 6), central decisions have already been made for the reading aloud workshops. How do student teachers choose their picturebook and how do they deal with the picturebook's ambiguity and openness to interpretation?
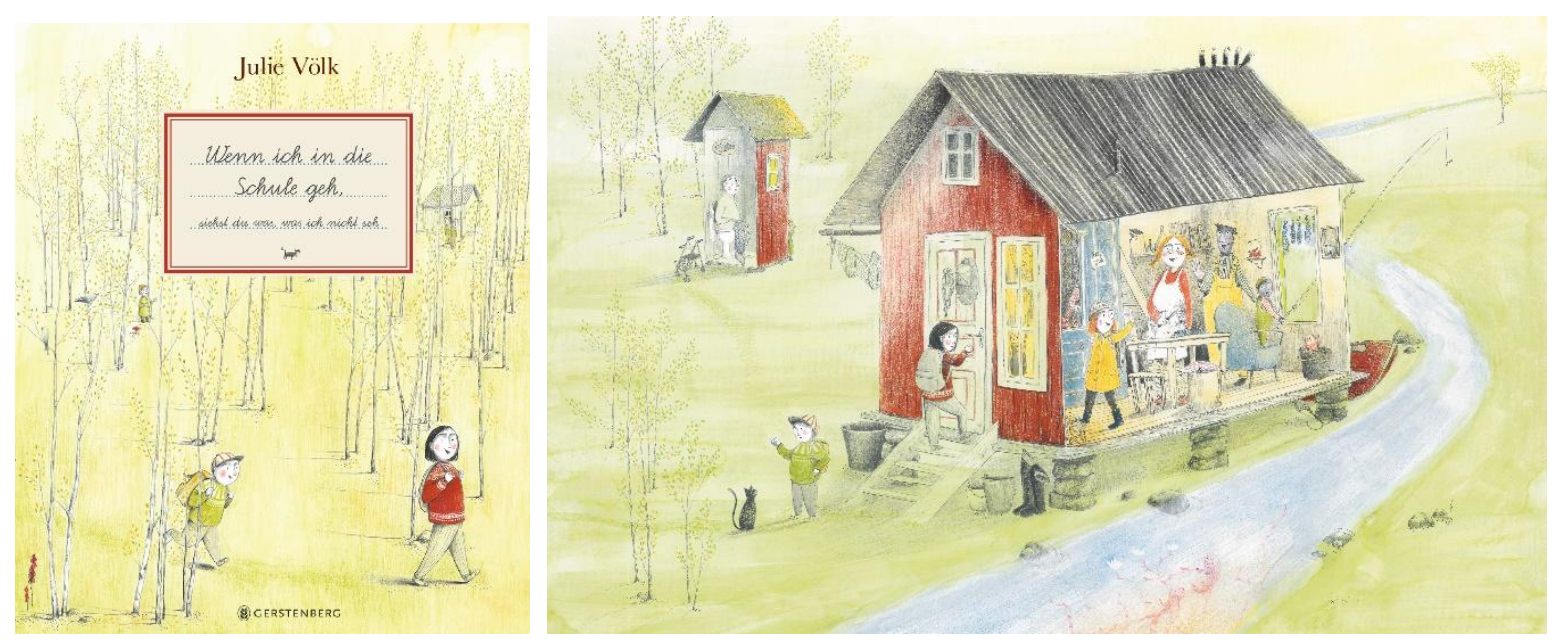

Figure. 6. (C) Julie Völk (illus.), from: Wenn ich in die Schule geh, siehst du was, was ich nicht seh, Gerstenberg Verlag 
The student teachers in one group describe their choice as follows:

The book caught our eye and aroused our interest, especially because of the tender and detailed illustrations. At first, we were sceptical about the extent to which one can read a book that has no text at all. But the scepticism changed quickly and became an enriching challenge for us. (Seminar paper, Reading aloud, group 4, p. 12)

As the student teachers write in their seminar paper, they were particularly convinced by the pictorial design of the picturebook, by the "tender and detailed illustrations". Thus, it is not the subject matter that is the focus of the selection decision, but the way in which the story is told visually. The lack of text in the story initially led to irritation - as is often the case among adult readers. The student teachers use a conceptual transformation to illustrate their conscious handling of this irritation: the student teachers turn the "scepticism" initially caused by [...] they were particularly convinced by the pictorial design of the picturebook, by the "tender and detailed illustrations". Thus, it is not the subject matter that is the focus of the selection decision, but the way in which the story is told visually. the missing texts into an (enriching) "challenge". This conceptual transformation illustrates a conscious decision to engage with the unfamiliar and to see it as something that one can grow from. The student teachers also made the richest detail of the visual narrative fruitful for the dialogic exchange with the children in conversation. For example, starting from the mobility walker in front of the outdoor toilet in the background of the picture and the tail fin of the elderly lady sitting in it (Figure. 6), a conversation about the name and function of walking aids and their use by their own grandparents as well as the surprise of seeing mermaids in the story developed.

\subsection{Student teachers' research question and didactic arrangement}

As a starting point for the design of their reading aloud workshops, the student teachers were asked to formulate a research question, which was a great challenge for many. What theoretical and didactic foundations underlie the research question and the didactic arrangement? In their seminar paper, the student teachers in the group that used the When I go to school... picturebook formulated the following research question: 
To what extent do the children follow the traces of the individual characters throughout the book and compare the situations with their own experiences? (Seminar paper, Reading aloud, group 4, p. 18)

From the student teachers' formulation of the research question, it is evident that they have engaged with literary reception research, which sees the connection of fictional worlds with real experiences as a central moment in literary learning (Spinner, 2006; Wieler, 2018). The focus on the characters in the story is also evidence that the student teachers are aware of children's interests in stories which have been pointed out by the research on reading socialisation (Wieler et al., 2008).

From the student teachers' formulation of the research question, it is evident that they have engaged with literary reception research, which sees the connection of fictional worlds with real experiences as a central moment in literary learning

In their didactic arrangement, the student teachers assign particular importance to spatial design (Figure. 7).
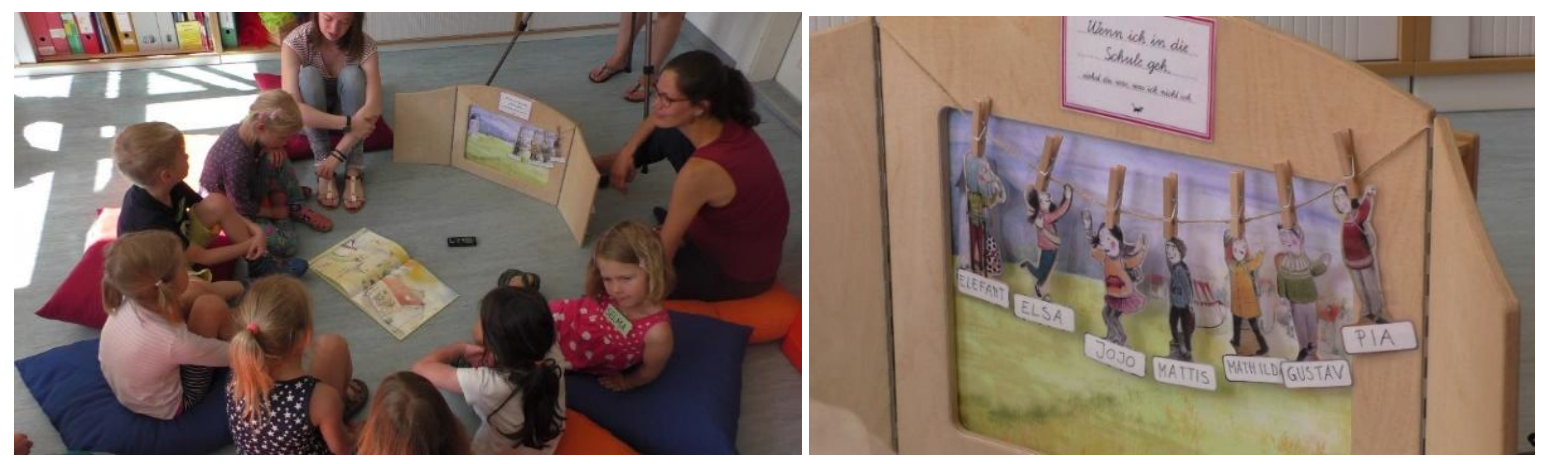

Figure. 7. Talking about the picturebook story

They describe their reflections on the prepared environment as follows:

After the joint welcome, the children were greeted by a reading corner which had already been prepared. Cushions arranged in a circle and the kamishibai standing there invited the children to read aloud. The book itself remained in the middle of the circle for a long time during the conversation, clearly visible to all girls and boys. (Seminar paper, Reading aloud, group 4, p. 18) 
The conviction that a "welcoming" environment is needed for "literary sociability" (Mattenklott, 1982 ) is evident from the student teachers' reflections. This includes, on the one hand, the circle as a suitable seating arrangement for conversations, especially about literature, and on the other hand, the choice of seat cushions on the floor (instead of chairs or seat cubes), which create a cosy and less distant atmosphere and might be familiar from everyday life at kindergarten. The student teachers also explicitly refer to the visibility of the picturebook for all children in the centre of the circle; this is particularly significant given that making a picture book visible to all children in this way does not always form part of everyday teaching practice in primary schools in Germany (Kruse, 2016). The kamishibai that the student teachers choose to introduce the characters one by one into the stories, to give them names and thus make them memorable, is also used as a medium to close the semicircle of the seat cushions into a circle. The children sit in a semicircle so that they can see the book well; the circle is closed by the kamishibai, creating a cosy picture book viewing situation.

\subsection{Connecting fiction and reality in the picturebook discussion}

The student teachers pay special attention to the first double-page spread in the picturebook discussion with the children. It is this page that introduces the story, represents the starting point of the plot, and introduces the characters (Figure. 8).

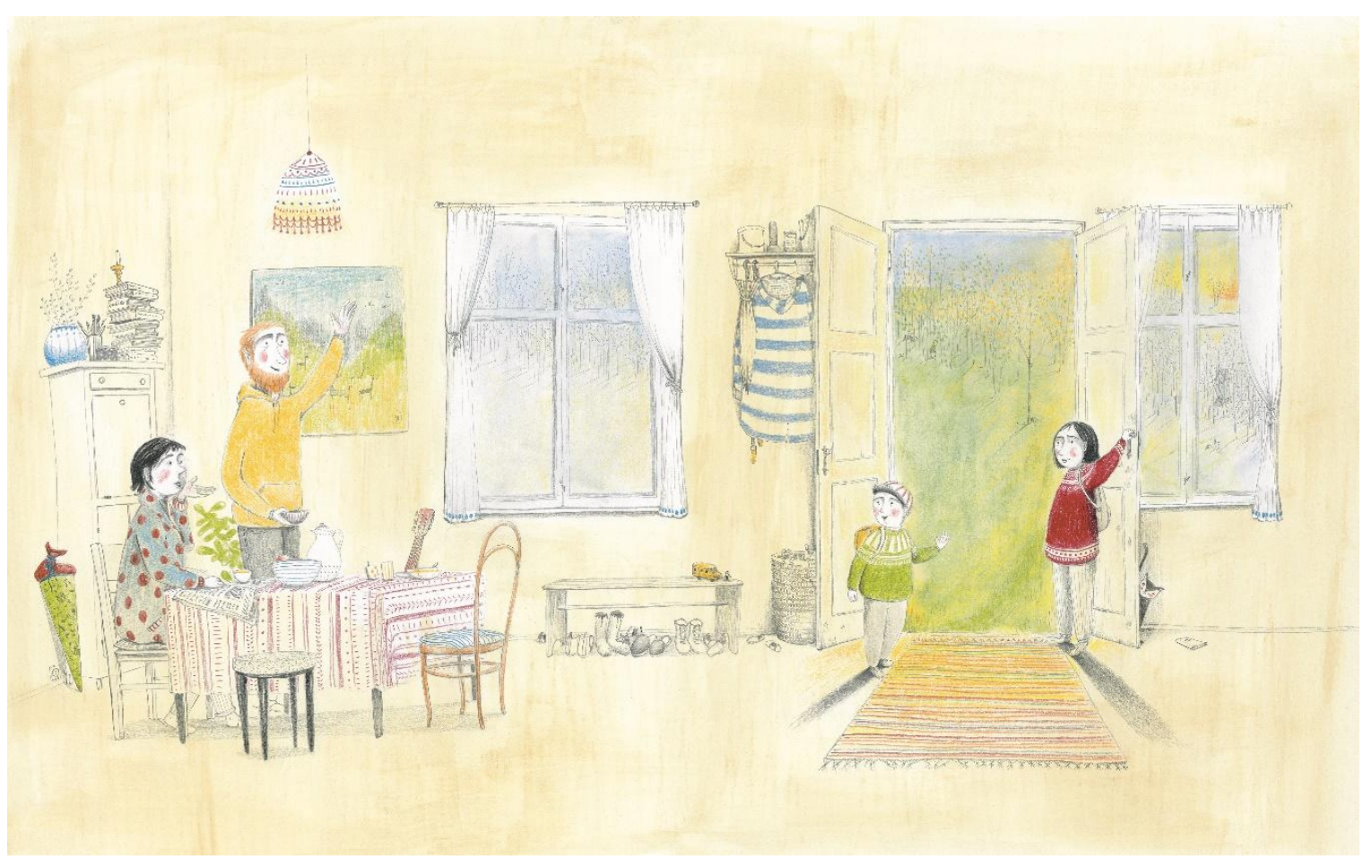

Figure. 8. ( Julie Völk (illus.), from: Wenn ich in die Schule geh, siehst du was, was ich nicht seh, Gerstenberg Verlag 
On this double-page spread we see a family's living room, as if in a theatre setting. On the left, the mother is sitting, and the father is standing at the breakfast table, which is still set, with cereal bowls and a newspaper lying on it. On the right side of the picture we see two children, of different heights, standing with their satchels on their backs at the open door that leads directly outside. They cast long shadows into the room through the morning sun. The parents say goodbye to their two children: the mother sends a kiss through the air with her flat hand held in front of her mouth and the father waves with his arm raised and smiles. The (smaller) boy waves back, while the (taller) girl is already holding the door handle and looks ready to go. In the background of the picture, behind the parents in the corner of the room, leaning against the wall and a cupboard, we see a 'school cone', a sign that the younger of the two children has probably just started school. In order to understand - in a national, and especially in an international context - what the tradition of school cones means to the children who participated in our study, a brief cultural-historical digression is needed. In Saxony, where the TU Dresden is located, the school cone is called a "Zuckertüte" (sugar cone) as it contains lots of sweets to "sweeten" the start of school. The tradition of the school cones or rather Zuckertüten originally comes from Saxony and Thuringia and has great significance there compared to other countries and compared to other federal states in Germany (Deckert-Peaceman, 2011). For example, the sugar cones there are significantly larger in size and length, are given away in greater numbers and the associated celebrations are also larger and numerous: for example, in addition to the actual school induction ceremony on the first day of school with the whole family, a "Zuckertütenfest" (sugar cone party) is also celebrated in the kindergarten just before the summer holidays start to say goodbye to the preschool children. Below, an excerpt from the transcript of the conversation between student teachers and children (with anonymised names) about this doublespread page is presented (Figure. 8, s. transcription conventions in the appendix), followed by its analysis ${ }^{1}$.

\footnotetext{
1 The transcription conventions are based on the minimal transcript of GAT 2 (Gesprächsanalytisches Transkriptionssystem, Selting et al., 2009).
} 


\begin{tabular}{|c|c|c|}
\hline 207 & Student 1 & this is the first page of our book \\
\hline 208 & Aaron & school cone \\
\hline 209 & Student 1 & and you can have a look at this page \\
\hline 210 & Student 2 & you can slide a little bit more ( ) \\
\hline 211 & Aaron & school cone \\
\hline 212 & Student 1 & and my first question i have for you is what do you think (.) \\
\hline 213 & & where the two children are going ${ }^{\circ} \mathrm{h}$ where they [run to ] \\
\hline 214 & Children & [to school] \\
\hline 215 & Student 1 & in the school you think but why do you think that you can \\
\hline 216 & & [clarify that ] \\
\hline 217 & Aaron & [because of the] school cone \\
\hline 218 & Student 1 & because of the school cone \\
\hline 219 & Mia-Lucia & to learn to read \\
\hline 220 & Student 1 & to learn to read (.) exactly but what do you see in the picture \\
\hline 221 & & why do you think that they go to school \\
\hline 222 & Student 2 & how could one recognise this \\
\hline 223 & Naomi & by the school bag \\
\hline 224 & Student 1 & on the back \\
\hline 225 & Aaron & yes \\
\hline 226 & Student 1 & (2.0) do you have another idea the school cone is already a \\
\hline 227 & & pretty good indicator \\
\hline 228 & Aaron & yes I have the \\
\hline 229 & Student 1 & a very nice hint (.) yes (.) you have seen it right away \\
\hline 230 & Helen & to the school cone party maybe \\
\hline 231 & Student 1 & to the school cone party did you already have it in \\
\hline 232 & & kindergarten \\
\hline 233 & Children & yes \\
\hline 234 & Mia-Lucia & there we have shown snow white \\
\hline 235 & Aaron & and $i$ was the leader of all the dwarves \\
\hline 236 & Student 1 & yes \\
\hline 237 & Naomi & i was snow white \\
\hline 238 & Mia-Lucia & i was the evil queen \\
\hline 239 & Student 1 & yeah (.) so you all agree that they want to go to school \\
\hline
\end{tabular}

Figure. 9. Transcript of the key incident "school cone"

To what extent do the student teachers succeed in making connections between fiction and real experiences when talking to the children? Before the student teachers ask their first question (but 
after the first child discovers the school cone on the picture), they invite the children to look at the double-spread page and ask them to "move over a bit more". This reveals three aspects: looking at a picture requires time (temporality), looking at a picturebook is connected to closeness to each other (physicality and sociality) and it requires an unrestricted view of the pictures (materiality). Only when this situation has been established does a student teacher formulate the first impulse question about a possible path the children could take. Several preschool children express the assumption that the children are going to school, whereupon the student teachers ask them to justify their assumption: "Why do you think that?", and further on also "What do you see in the picture?", "How could one recognise this?" With these formulations, the student teachers emphasise the space of fiction, which leaves various possibilities open (they do not ask "How can you tell?", "How do you know?" or "Why is it like that?", which would require more unambiguous answers). Subsequently, the children express different assumptions, for example, "because of the school cone", "to learn to read", "by the school bag", "to the school cone party, maybe", mixing up reasons and motivations. In some cases, they also remain explicitly linguistically in the space of possibility, for example, through the "fictionality signal" "maybe" (Dehn, 2019; Hoffmann, 2019).

In the second part of this passage of conversation, a student initiates the transition to the preschool children's own experiences based on the children's

The children's own imminent start at school, with the associated transformation from pre-schooler at kindergarten to schoolchild, is symbolically anticipated here by telling the student teachers about their transformation into fairy tale characters. Through storytelling, this transformation becomes a meaningful memory for the children. expression "Zuckertütenfest" (school cone party), asking, "Did you already have it in kindergarten?" In doing so, she initiates the literary learning process of connecting one's own involvement and accurate textual perception (Spinner, 2006), the connection between fiction and reality (Wieler, 2018). Although the question is asked in a closed manner and is initially answered by several children with the word "yes", three children, without being asked again and with obvious enthusiasm, talk about the fact that they performed a play based on a fairy tale ("Snow White") at their Zuckertütenfest and explain which roles they took on: "leader of all the dwarves", "Snow White" and "evil queen". The children's own imminent start at school, with the associated transformation from pre-schooler at kindergarten to schoolchild, is symbolically anticipated here by telling the student teachers about their transformation into fairy tale characters. Through storytelling, this transformation becomes a meaningful memory for the 
children. Finally, one of the student teachers leads the conversation back to the picturebook by summarising that the story is about the journey to school from the children's perspective, again opening up spaces of possibility in her formulation by perspectivising the interpretation ("so you all agree that they want to go to school") (Hoffmann, 2019).

In their own conversation analyses in their seminar papers, the student teachers describe their oscillations between fiction and reality with the children in conversation as follows:

During the conversation there were on the one hand passages in which the children explained their experiences of their own accord, and on the other hand, we asked questions which encouraged the children to talk about their experiences. (Seminar paper, Reading aloud, group 4, p. 26)

In addition to the passage just analysed, in which the question impulse comes from the student teachers, there are also others in which the children talk about their experiences without prompting, for example in a picture where a mobility walker is depicted (Figure. 6) and a child says that his grandfather also has one.

\subsection{Student teachers' reflections on their own learning process}

In the last section of their seminar paper, the student teachers were asked to reconstruct their own learning processes. What insights do the student teachers gain in the research process and how do they gain them? One student from the group "When I go to school..." offers the following insights, among others:

In the course of the preparations, I realised what a great challenge it can be to prepare a read aloud. [...] It was important what atmosphere we wanted to create, and which objects to include. We had to think about how to read the book aloud, what questions to ask, what our goal is, and to what extent we can inspire and captivate the children. [...]

For my future teaching career, I therefore take it for granted that reading aloud is not something that should simply be done on the side, but something that requires extensive preparation. (Seminar paper, Reading aloud, group 4, p. 30f.) 
The pedagogical and didactic learning processes formulated by the students result from the "challenge" of preparing a reading discussion. These learning processes can be located on different levels, as follows (the quoted phrases in brackets are taken from the student teachers' seminar papers): Spatiality ("what atmosphere we wanted to create"), Materiality ("which objects to include"), Performativity ("how to read the book aloud"), Cognition ("what questions we ask", "what our goal is") and Motivation ("to what extent we can inspire and captivate the children"). The conclusion that the student teachers themselves draw from their experiences is that "reading aloud is not something that should simply be done on the side, but something that requires extensive preparation". While this insight is not original, considering the typical "casualness" of reading aloud which has been observed in empirical classroom research (Kruse, 2016), or the reading aloud situations of "five-minute stories" accompanying the breakfast break, which can be observed again and again in the context of school internships, its importance should be emphasised.

\section{Conclusion}

The presented key incident analyses have provided important insights into Didactic Research Labs on reading picturebooks. With regard to the potential of research-based learning in the context of university teacher education and with a view of picturebooks as conversation and storytelling occasions for children, it can be said in summary that the student teachers engaged with the ambiguity of the wordless picturebook and also had an open conversation with the children. They repeatedly made the children create connections between the fictional story and their own experiences. They became aware that the preparation, implementation, and reflection of reading and talking about picturebooks requires time and they are willing to invest this time. The student teachers did not gain their knowledge from didactic instruction by the lecturer, but rather through their own research process - by practical experience with picturebooks, in conversation and interaction with children, and through theoretical reflection against the background of an intensive study of the literature.

In addition to the personal encounter with the children, the analyses presented here have shown that important aspects for the process of inquiry-based and dialogic learning in connection with children's reception of picture books are the space, the book selection, the independent work in the group, the inquiry-based observational approach, the time for reflection and writing as a heuristic process. In this regard, we can note the following: 
- The flexible furniture, children's literature and didactic material in the room of a Primary Research Lab offer student teachers scope for creativity that they can use in a literary-aesthetic way.

- On the one hand, the broad pre-selection of picturebooks by the lecturers guaranteed literaryaesthetic narratives and action-relevant themes for kindergarten and school children. On the other hand, it gave the student teachers enough freedom of choice to set their own thematic and aesthetic priorities in their didactic arrangements in the reading aloud workshops.

- Although developing the didactic arrangement through independent group work requires a significant amount of time, since the scientific literature has to be read independently and all didactic decisions have to be discussed and agreed upon in the group, it promotes the student teachers' ability to reflect and improves the 'feedback culture'. They design the didactic situations together in discussion and can work through and discuss different possibilities.

- The inquiry-based observational approach in the implementation of the reading workshop through video and audio recordings and observation protocols provides the data for analysis and reflection and shifts the student teachers' focus and orientation from themselves (as designers of the situation) to the children (and their linguistic-literary learning processes).

- Allowing time and space for reflection (orally in the seminar discussion and in writing in the seminar paper) ensures that student teachers think through their own literary practice and anticipate future pedagogical-didactic challenges.

- The heuristic function of writing plays a special role in the context of research-based learning. During the transcription of the recorded conversations, the student teachers already gain insights into their own language practices in conversations about literature and those of the children. During the writing of the seminar papers, these insights can then be developed and structured.

The central moment in the whole concept of the Didactic Research Labs is the encounter between student teachers and children in the context of the university. This is not only a fruitful professionalisation opportunity for the student teachers, but also a special experience for the kindergarten and primary school children in an educational setting that is otherwise inaccessible to them in everyday life. This is demonstrated by the children's interest, concentration and, in 
particular, their observable enjoyment of the literary activities offered by the student teachers and the shared literary experiences in the group.

\section{Children's Literature Citations}

Bergström, G. (1982). Nur Mut, Willi Wiberg! (G. Bergström, Illus.). Oetinger.

Bertron, A. (2016). Frau Hoppes erster Schultag (A. Scheffler, Illus.). Beltz. [Bertron, A. (2020). Miss Hoppy's First Day at School (A. Scheffler, Illus.). Macmillan Children's Books.]

Child, L. (2005). Nein! Zur Schule geh ich nicht! (L. Child, Illus.). Carlsen. [Child, Lauren (2007). I am Too Absolutely Small for School (L. Child, Illus.). Orchard Books.]

Damm, A. (2011). Regenwurmtage (A. Damm, Illus.). Moritz.

Donaldson, J. (2007). Flunkerfisch (A. Scheffler, Illus.). Beltz. [Donaldson, J. (2007). Tiddler (A. Scheffler, Illus.). Scholastic UK]

Fährmann, W. (1994). Ich will in die Schule (A. Ritter, Illus.). Heinrich Ellermann.

Gaetzi, C. (1999). Als ich klein war (C. Gaetzi, Illus.). pro juventute.

Hole, S. (2009). Garmans Sommer (S. Hole, Illus.). Carl Hanser. [Hole, S. (2008). Garmann's Summer (S. Hole, Illus.). Wm. B. Eerdmans.]

Hula, S. (2013). Die coolste Schule der Welt (I. Hattenhauer, Illus.). Residenz.

Iwasa, M. (2017). Viele Grüße, Deine Giraffe (J. Mühle, Illus.). Moritz. [Iwasa, M. (2017). Yours Sincerely, Giraffe (J. Mühle, Illus.). Gecko Press.]

Lindgren, A. (1980). Ich will auch in die Schule gehen (I. Wikland, Illus.). Oetinger. [Lindgren, A. (1980). I Want to Go to School Too (I. Wikland, Illus.). Methuen.]

Nöstlinger, C. (1987). Schulgeschichten vom Franz. Oetinger.

Ramos, M. (2012). Nur Mut, kleiner Luis (M. Ramos, Illus.). Moritz.

Regnaud, J. (2009). Meine Mutter ist in Amerika und hat Buffalo Bill getroffen (É. Bravo, Illus.). Carlsen. [Regnaud, J. (2009). My Mommy Is in America and She Met Buffalo Bill (É. Bravo, Illus.). Ponent Mon.

Schärer, K. (2006). Zwei dicke Freundinnen (K. Schärer, Illus.). Sauerländer.

Scieszka, J. (2001). Kwatsch (Julius P.) (L. Smith, Illus.). Carlsen. [Scieszka, J. (2001). Baloney (Henry P.) (L. Smith, Illus.). Viking Press.]

Sperring, M. (2018). Der Bär ist los! Warum Bären nicht in die Schule gehören (B. Teckentrup, Illus.). arsEdition. [Sperring, M. (2017). Never Take a Bear to School (B. Teckentrup, Illus.). Orchard Books.]

Teckentrup, B. (2018). Die Schule (B. Teckentrup, Illus.). Jacoby und Stuart. [Teckentrup, B. (2020). School. Come in and take a closer look (B. Teckentrup, Illus.). Prestel.]

Teich, K. (2014). Wir sind 1a (K. Teich, Illus.). Carlsen.

Tolstoj, L., \& Beneduce, A. K. (2000). Philipok (G. Spirin, Illus.). Esslinger. [Tolstoy, L., \& Beneduce, A. K. (2000). Philipok (G. Spirin, Illus.). Philomel.]

Völk, J. (2018). Wenn ich in die Schule geh, siehst du was, was ich nicht seh (J. Völk, Illus.). Gerstenberg. 


\section{References}

Arizpe, A., Colomer, T., \& Martínez-Roldán, C. (2014). Visual Journeys Through Wordless Narratives. An International Inquiry With Immigrant Children and The Arrival. Bloomsbury.

Baacke, D. (2018a). Die 0- bis 5-Jährigen. Einführung in die Probleme der frühen Kindheit. Beltz Juventa.

Baacke, D. (2018b). Die 6- bis 12-Jährigen. Einführung in die Probleme des Kindesalters. Beltz Juventa.

Brandt, B., Hoffmann, J., Ibelshäuser, B., Wagener, M., \& Werner, Ch. (2021). 100 Jahre Grundschule in Deutschland - eine Schule für alle? In N. Böhme, B. Dreer, H. Hahn, S. Heinecke, G. Mannhaupt, \& S. Tänzer (Eds.), Mythen, Widersprüche und Gewissheiten der Grundschulforschung. Eine wissenschaftliche Bestandsaufnahme nach 100 Jahren Grundschule (pp. 39-51). Springer VS.

Bruner, J. S. (1986). Actual Minds, Possible Worlds. Harvard University Press.

Bruner, J. S. (1996). The Culture of Education. Harvard University Press.

de Boer, H. (2012). Pädagogische Beobachtung. Pädagogische Beobachtungen machen - Lerngeschichten entwickeln. In H. de Boer, \& S. Reh (Eds.), Beobachtung in der Schule - Beobachten lernen (pp. 65-84). Springer VS.

Deckert-Peaceman, H. (2011). Der Brauch der Zuckertüte als Medium. In H. de Boer, H. Deckert-Peaceman, \& K. Westphal (Eds.), Irritationen - Befremdungen - Entgrenzungen. Fragen an die Grundschulforschung (pp. 61-77). Johann-Wolfgang-Goethe-Universität.

Dehn, M. (2004). Zwischen Text und Bild. Schreiben und Gestalten mit neuen Medien. Fillibach.

Dehn, M. (2019). Visual Literacy, Imagination und Sprachbildung. In J. Knopf, \& U. Abraham (Eds.), BilderBücher. Band 1 Theorie (2nd ed., 121-130). Schneider Hohengehren.

Dehn, M., Merklinger, D., \& Schüler, L. (2014). Narrative Acquisition in Educational Research and Didactics. In P. Hühn, J. Ch. Meister, J. Pier, \& W. Schmid (Eds.), Handbook of Narratology (pp. 489-506). De Gruyter.

Ertl-Schmuck, R., \& Hoffmann, J. (Eds.) (2020). Spannungsfelder zwischen Theorie und Praxis in der Lehrer/innenbildung - Interdisziplinäre Perspektiven. Beltz Juventa.

Evans, J. (Ed.) (2015). Challenging and Controversial Picturebooks. Creative and Critical Responses to Visual Texts. Routledge.

Fludernik, M. (2009). An Introduction to Narratology. Routledge.

Herrmann, F. (2019). Didaktische Forschungswerkstatt zum kreativen Schreiben - Ein fächerverbindendes Seminar im Format forschenden Lernens. GDSU-Journal, 9(9), 9-30.

Hoffmann, J. (2017). Graphic Novels as an Invitation to Read, See and Imagine. Filoteknos. Children's Literature - Cultural Mediation - Anthropology of Childhood, 7, 40-53. [https://www.ifp.uni.wroc.pl/wpcontent/uploads/Filoteknos/Filoteknos_07.pdf, 15.07.2021]

Hoffmann, J. (2019). Grafisch erzählte Geschichten im Bilderbuchkinogespräch - David Wiesners Herr Schnuffels in der Grundschule. MiDU - Medien im Deutschunterricht, 1(1), 43-65. https://journals.ub.unikoeln.de/index.php/midu/article/view/26/9,

Hoffmann, J. (2020). Narratives Lernen in Unterrichts- und Professionsforschung. In R. Ertl-Schmuck, \& J. Hoffmann (Eds.), Spannungsfelder zwischen Theorie und Praxis in der Lehrer/innenbildung Interdisziplinäre Perspektiven (pp. 61-89). Beltz Juventa. 
Hoffmann, J. (2021). Comics in der Schule - Schule im Comic. Zum gegenseitigen Verweischarakter von biographischen und literarischen Erfahrungen. In M. Engelns, U. Preußer, \& F. Giesa (Eds.), Comics in der Schule. Theorie und Unterrichtspraxis (pp. 197-224). Ch. A. Bachmann.

Hoffmann, J., Hermann, F., \& Schweda, M. (2019). Lesen, Schreiben, Sehen, Zeichnen, Erzählen ... und darüber ins Gespräch kommen - in der Lern- und Forschungswerkstatt Grundschule an der TU Dresden. In R. Baar, A. Feindt, \& S. Trostmann (Eds.), Struktur und Handlung in Lernwerkstätten. Hochschuldidaktische Räume zwischen Einschränkung und Ermöglichung (pp. 173-184). Julius Klinkhardt.

Huber, L. (2013). Warum Forschendes Lernen nötig und möglich ist. In L. Huber, J. Hellmer, \& F. Schneider (Eds.), Forschendes Lernen im Studium. Aktuelle Konzepte und Erfahrungen (2nd ed., pp. 9-35). UniversitätsVerlagWebler.

Kroon, S., \& Sturm, J. (2007). Key Incident Analysis and International Triangulation. In W. Herrlitz, S. Ongstad, \& P. H. van den Ven, (Eds.), Research on mother tongue education in a comparative international perspective. Theoretical and methodological issues (pp. 96-114). Rodopi.

Krummheuer, G. (2000). Interpretative classroom research in primary mathematics education. Some preliminary remarks. Zentralblatt für Didaktik der Mathematik, 32(5), 124-125.

Kruse, I. (2016). Gut vorlesen. Textpotenziale entfalten. In A. Pompe (Ed.), Literarisches Lernen im Anfangsunterricht (3rd ed., pp.102-121). Schneider Hohengehren.

Kümmerling-Meibauer, B. (Ed.) (2014). Picturebooks. Representation and Narration. Routledge

Mattenklott, G. (1982): Literarische Geselligkeit - Schreiben in der Schule. Mit Texten von Jugendlichen und Vorschlägen für den Unterricht. J. B. Metzler.

Mieg, H. A. (Ed.) (2019). Inquiry-Based Learning - Undergraduate Research. The German Multidisciplinary Experience. Springer Open.

Merklinger, D. (2011). Frühe Zugänge zur Schriftlichkeit. Eine explorative Studie zum Diktieren. Fillibach.

Merklinger, D., \& Preußer, U. (2014). Im Vorlesegespräch Möglichkeiten für literarisches Lernen eröffnen. Steinsuppe von Anaïs Vaugelade. In G. Scherer, S. Volz, \& M. Wiprächtiger-Geppert (Eds.), Bilderbuch und literar-ästhetische Bildung. Aktuelle Forschungsperspektiven (pp. 155-173). WVT.

Naujok, N. (2018). Erzählbrücken - Szenisches Erzählen für neu zugewanderte Kinder und das unterstützende Potenzial von Literalität. Leseforum Schweiz - Literalität in Forschung und Praxis, 19(2), 1-17. www.leseforum.ch

Schmitz, C. M., \& Weiss, J. (2016). Sprache. Ein Lesebuch von A bis Z. Wallstein.

Selting, M. et al. (2009). Gesprächsanalytisches Transkriptionssystem 2 (GAT 2). Gesprächsforschung - OnlineZeitschrift zur verbalen Interaktion, 10, pp. 353-402. http://www.gespraechsforschung-ozs.de,

Spinner, K. H. (2005). Höreraktivierung beim Vorlesen und Erzählstruktur. In P. Wieler (Ed.), Narratives Lernen in medialen und anderen Kontexten (pp. 153-166). Fillibach.

Spinner, K. H. (2006). Literarisches Lernen. Praxis Deutsch, 33(200), 6-16.

Staiger, M. (2013). Zur Komplexität des Erzählens im Bilderbuch. Narratologische Desiderate und Ansatzpunkte. In I. Kruse, \& A. Sabisch (Eds.), Fragwürdiges Bilderbuch. Blickwechsel - Denkspiele Bildungspotenziale (pp. 65-75). Kopaed.

Ulich, M., \& Ulich, D. (1994). Literarische Sozialisation. Wie kann das Lesen von Geschichten zur Persönlichkeitsentwicklung beitragen? Zeitschrift für Pädagogik, 40(5), 821-834. 
Vollbrecht, R. (2010). Der sozialökologische Ansatz der Mediensozialisation. In D. Hoffmann, \& M. Lothar (Eds.), Mediensozialisationstheorien. Neue Modelle und Ansätze in der Diskussion (2nd ed., pp. 93-108). Springer VS.

Wegener, C. (2018). Comics im sozialökologischen (Forschungs-)Feld. Eine sozialräumliche Verankerung. In Ch. Dallmann, A. Hartung-Griemberg, A. Aigner, K.-Th. Buchele, (Eds.), Comics. Interdisziplinäre Perspektiven aus Theorie und Praxis auf ein Stiefkind der Medienpädagogik. Festschrift für Ralf Vollbrecht (pp. 153-166). Kopaed.

Wells, G. (2015). Dialogic Learning: Talking our Way into Understanding. In T. Dragonas, K. J. Gergen, S. McNamee, \& E. Tseliou (Eds.), Education as Social Construction: Contributions to Theory, Research and Practice (pp. 62-90). Taos Institute.

Wieler, P., Brandt, B., Naujok, N., Petzold, J., \& Hoffmann, J. (2008). Medienrezeption und Narration. Gespräch und Erzählung als Verarbeitung der Medienrezeption im Grundschulalter. Fillibach.

Wieler, P. (2014). Reden, Zuhören, Bedeutung konstruieren bei der gemeinsamen Bilderbuchrezeption. In J. Knopf, \& U. Abraham (Eds.), BilderBücher. Bd. 1 Theorie (pp. 184-195). Schneider Hohengehren.

Wieler, P. (2018). Sprachlich-ästhetische Literaturerfahrung als Beitrag zur Identitäts- und Sprachentwicklung jüngerer Kinder. Leseräume. Zeitschrift für Literalität in Schule und Forschung, 5(4), 35-48.

\section{How to cite this paper:}

Hoffmann, J. (2021). Student Teachers and Kindergarten Children Talking about Picturebooks Focusing School. Journal of Literary Education, (4), 69-95. https://doi.org/10.7203/JLE.4.21024 